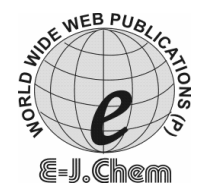

http://www.e-journals.net

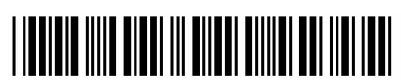

ISSN: 0973-4945; CODEN ECJHAO

E-Journal of Chemistry

Vol. 5, No.3, pp. 431-434, July 2008

\title{
Evaluation of the Effect of Azo Group on the Biological Activity of 1-(4-Methylphenylazo)-2-naphthol
}

\author{
V. MKPENIE, G. EBONG, I. B. OBOT ${ }^{*}$ and B. ABASIEKONG \\ Department of Chemistry, \\ University of Uyo, P. M. B. 1017, Uyo, Nigeria. \\ "Department of Science and Technology, \\ Akwa Ibom State Polytechnic,P.M.B. 200, Ikot Ekpene, Nigeria. \\ proffoime@yahoo.com
}

Received 3 September 2007; Accepted 2 December 2007

\begin{abstract}
Azo-2-naphthol and 2-naphthol were tested against five microorganisms: Staphylococcus aureus, Escherichia coli, Bacillus subtilis, Pseudomonas aeruginosa and Streptococcus faecalis. 2-Naphthol was slightly active while azo-2-naphthol was highly active against all the bacteria species tested. The presence of azo group contributed more than $60 \%$ of the antibacterial activities exhibited by azo-2-naphthol on all the bacteria tested.
\end{abstract}

Keywords: Azo compound; 2-Naphthol; Antibacterial activity; $p$-Toluidine.

\section{Introduction}

Azo compounds constitute one of the largest classes of industrially synthesized organic compounds. They are important in drugs and cosmetics ${ }^{1}$ and show a variety of interesting

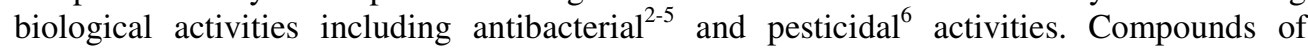
naphthalene have been reported to show a variety of biological activities including antimicrobial activities ${ }^{7,8}$, HIV-1 integrase inhibitory effect ${ }^{9}$, anti-inflammatory activity ${ }^{10}$, inhibition of protein tyrosine kinases ${ }^{11}$ and inactivation of enveloped viruses ${ }^{12}$. Azo compounds of naphthols have been extensively used as dye ${ }^{13-15}$, but the biological activity is less reported. Since compounds with azo moiety and naphthalene moiety have been reported to exhibit biological activities independently, it is therefore obvious that azo compounds of 2-naphthol will show a higher biological activity.

In this paper, we synthesize azo compound of naphthalene and use it to investigate its inhibitory effect on the biological activities of some bacteria. The contribution of the azo moiety toward the biological activity is also evaluated. 


\section{Experimental}

\section{General}

All chemicals used were of analytical grade. The IR spectra were recorded on a Shimadzu FTIR-IR Prestige (200VCE) as $\mathrm{KBr}$ pellets. The $\mathrm{C}, \mathrm{H}, \mathrm{N}$ data were determined using a Perkin-Elmer Instrument (200B).

\section{Synthesis of 1-(4-methylphenylazo)-2-naphthol}

The method used for the preparation of azo compounds has been described elsewhere ${ }^{13}$. A solution of hydrochloric acid was prepared by diluting $2 \mathrm{~mL}$ of the concentrated acid in $20 \mathrm{~mL}$ of distilled water. 10 mmole of $p$-toluidine $(1.074 \mathrm{~g})$ was added, stirred and cooled to $0^{\circ} \mathrm{C} .8 \mathrm{~mL}$ of aqueous sodium nitrite $(10.88 \mathrm{mmole}, 0.7507 \mathrm{~g})$ was added in drops maintaining the temperature between $0-5{ }^{\circ} \mathrm{C}$. The diazonium chloride formed was consecutively coupled with 10 mmole of 2-naphthol (1.449 $\mathrm{g}$ ) that was dissolved in $15 \mathrm{~mL}$ of $10 \%$ sodium hydroxide solution. The reaction mixture was stirred at $0^{\circ} \mathrm{C}$ for 1 hour. The red product that precipitated was recrystallized from ethanol (65\%); IR (KBr, $\left.\mathrm{cm}^{-1}\right)$ : 3520-3380 (Ar-OH), 3060-3020 (Stretching $\mathrm{CH}), 2926\left(\mathrm{CH}_{3}\right), 1632(\mathrm{C}=\mathrm{C}), 1450(\mathrm{~N}=\mathrm{N})$; Anal. Cald. for $\mathrm{C}_{17} \mathrm{H}_{14} \mathrm{~N}_{2} \mathrm{O}: \mathrm{C} 77.84, \mathrm{H}$ 5.38, N 10.68; found C 77.78, H 5.21, N 10.58.

\section{Antimicrobial activity}

The 2-naphthol and azo-2-naphthol were screened for the presence of antimicrobial constituents against five microorganisms: Staphylococcus aureus, Escherichia coli, Pseudomonas aeroginosa, Streptococcus faecalis and Basillus substilis using disk diffusion method $^{8}$. The tested compounds were dissolved in ethanol to give $10 \mathrm{mg} / 2 \mathrm{~mL}$ solutions. $20 \mu \mathrm{L}$ solutions of these were applied to sterile disks and placed on nutrient agar plates with the bacteria. The plates were incubated for 24 hours and the zones of inhibition were measured. Clarithromycin and cerftriflaxon were used as reference antibiotics. Ethanol showed no inhibition zones on all the bacteria tested.

\section{Results and Discussion}

The electrophilic substitution reaction of 2-naphthol at 1-position is well documented in the literature $^{16,17}$. 1-(4-methylphenylazo)-2-naphthol (azo-2-naphthol) 4 was prepared as a red solid from 2-naphthol $\mathbf{3}$ according to Scheme 1.

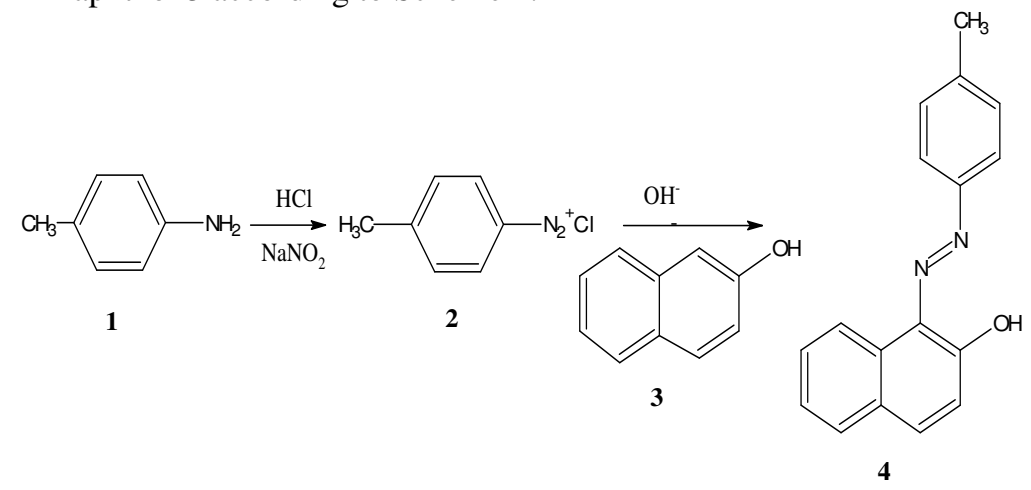

Scheme 1

The azo-2-naphthol was obtained in good yield, 65\%. The analytical data and IR spectral data support the product obtained. 
The azo-2-naphthol and 2-naphthol were examined in-vitro against bacteria species. The test results presented in Table 1 suggested that 2-naphthol was slightly active with inhibition zones 6-8 mm. Azo-2-naphthol, combining the activities of azo and naphthalene moieties recorded higher activity against all the bacteria with inhibition zones 17-22 $\mathrm{mm}$. Cerftriaxon and Clarithromycin are well known antibacterial substances and showed inhibition zones 11$13 \mathrm{~mm}$ and 5-7 $\mathrm{mm}$ respectively for the same pathogenic bacteria. The contribution of the azo moiety toward the antibacterial activity of azo-2-naphthol was evaluated (Table 1). The results showed that azo group contributed more than $60 \%$ of the total antibacterial activity of azo-2-naphthol for all the bacteria tested.

Table 1. The effects of azo moiety on the antibacterial activity of azo-2-naphthol

\begin{tabular}{lccccc}
\hline $\begin{array}{l}\text { Compound } \\
\text { Bacteria }\end{array}$ & Clarithromycin & Cerftriaxon & 2-aphthol & $\begin{array}{l}\text { Azo-2- } \\
\text { naphthol }\end{array}$ & $\begin{array}{l}\% \text { Inhibition* } \\
\text { (Azo moiety) }\end{array}$ \\
\hline $\begin{array}{l}\text { Staphylococcus } \\
\text { aureus }\end{array}$ & + & ++ & + & +++ & $\mathrm{a}$ \\
$\begin{array}{l}\text { Eschericia } \\
\text { coli }\end{array}$ & + & +++ & + & +++ & $\mathrm{a}$ \\
$\begin{array}{l}\text { Pseudomonas } \\
\text { aeruginosa }\end{array}$ & + & +++ & + & +++ & $\mathrm{b}$ \\
$\begin{array}{l}\text { Streptococcus } \\
\text { faecalis }\end{array}$ & - & ++ & + & +++ & $\mathrm{b}$ \\
Bacillussubstilis & + & ++ & + & +++ & $\mathrm{a}$ \\
\hline
\end{tabular}

*\% Inhibition (azo moiety) = ZOI (azo-2-naphthol) - ZOI (2-naphthol), ZOI (azo-2-naphthol)

Key to symbols

ZOI

Highly active

$=\quad$ Zone of inhibition

Moderately active

$=\quad+++($ inhibition zone $>12 \mathrm{~mm})$

Slightly active

$=\quad++$ (inhibition zone $9-12 \mathrm{~mm}$ )

Inactive

$\begin{array}{ll}= & +(\text { inhibition zone } 6-8 \mathrm{~mm}) \\ = & -(\text { inhibition zone }<5 \mathrm{~mm})\end{array}$

$\%$ Inhibition

$\%$ Inhibition

$=\quad \mathrm{a}(60-64 \%)$

$=\quad b(>64 \%)$

\section{Conclusion}

Screening of 2-naphthol and azo-2-naphthol independently against bacteria species afforded the evaluation of the contribution of azo moiety to the biological activity. With a high activity (inhibition zones, 17-22 $\mathrm{mm}$ ) against 2-naphthol (inhibition zones, 6-8 $\mathrm{mm}$ ), azo-2-naphthol exhibited a combined activities of both azo and naphthalene moieties. The azo moiety contributed more than $60 \%$ of the total biological activity exhibited by azo-2naphthol.

\section{References}

1. Marmion, D M, Handbook of U S Colourant; Wiley, New York, 1999, 23-26.

2. Awad, I M, Aly A A, Abdel Alim A M, Abdel Aal R A and Ahmed S H, J. Inorg. Biochem. 1998, 33, 77-89.

3. Makhsumov A G, Ergashev M S and Normatov F A, Pharm. Chem. J. 1991, 25. 
4. Ibrahim S A, Gahami M A, Khafagi, Z A and Gyar S A, J. Inorg. Biochem., 1991, 43, 1-7.

5. Jarahpour A A, Motamedifar M, Pakshir K, Hadi N and Zarei Z, Molecules, 2004, 9, 815-824.

6. Samadhiya S and Halve H, Orient. J. Chem., 2001, 17, 119-122.

7. $\quad$ Eid F A, El-Wahab A H F, Ali G A and Khafagy M M, Acta. Pharm., 2004, 54, 13-26.

8. Goksu S, Uguz M T, Ozdemir H and Secen H A, Turk. J. Chem., 2005, 29, 199-205.

9. Burke T R, Fesen M, Mazumder A, Yung J, Carothers A M, Grunberger D, Driscoll J, Pommier Y and John K, J. Med. Chem., 1995, 38, 4171-4178.

10. Huang M, Wu S, Wang J, Lin C, Lu S, Liao L and Shen A, Drug Dev. Res., 2003, 60, 261-269.

11. Burke T R, Lim R, Marquez V E, Li B H, Bolen J B, Stefanova I and Horak I D, J. Med. Chem., 1993, 36, 425-432.

12. Kasermann F, and Kempf C, Antiviral Research, 1998, 38, 55-62.

13. Eaton D C, Laboratory Investigation in Organic Chemistry; McGraw-Hill Inc, USA, 1989, 429-435.

14. Mohamed S K and Nour El-Din A M, J. Chem. Res, 1999, 8, 508-509.

15. Cumming W M and Howie G, J. Chem. Soc., 1933, 133-135.

16. Oakes J and Gratton P, J. Chem. Soc. Perkin Trans., 1998, 2, 2201-2206.

17. Hanusek J Machacekad V and Lycka, Dyes and pigments, 2007, 73, 326-331. 


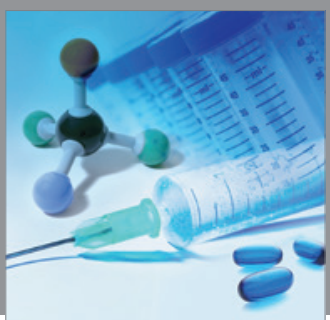

International Journal of

Medicinal Chemistry

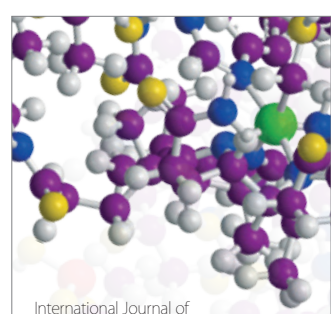

Carbohydrate Chemistry

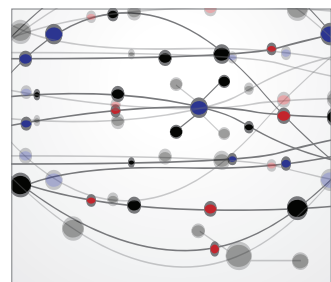

The Scientific World Journal
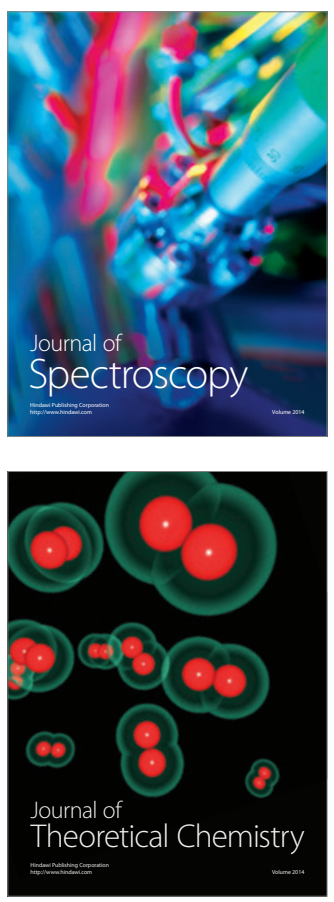
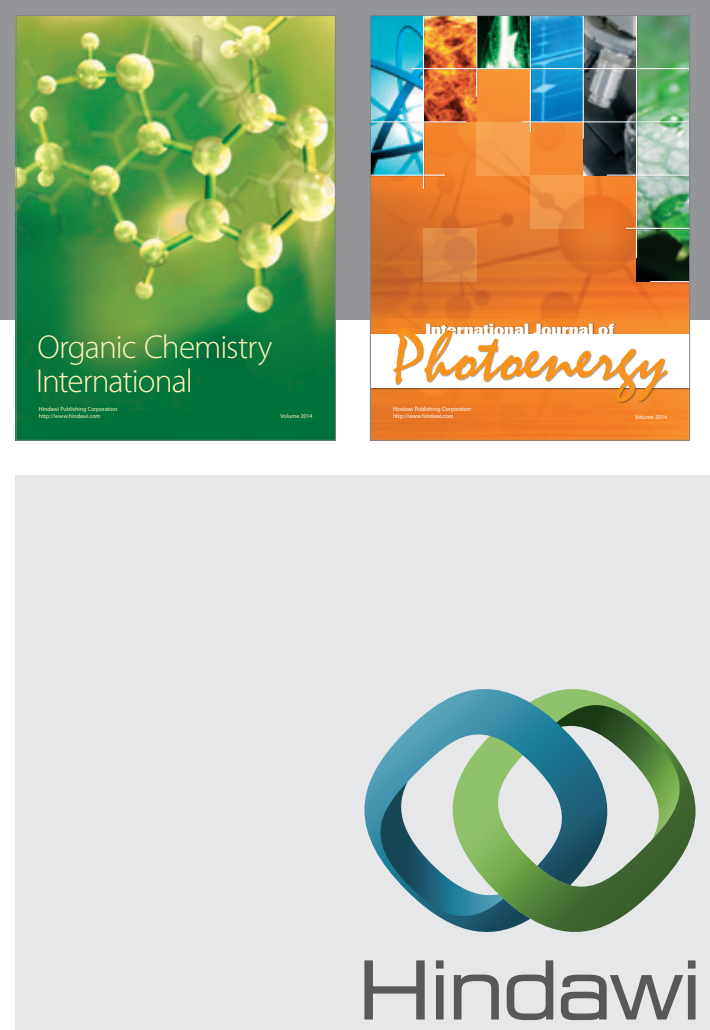

Submit your manuscripts at

http://www.hindawi.com
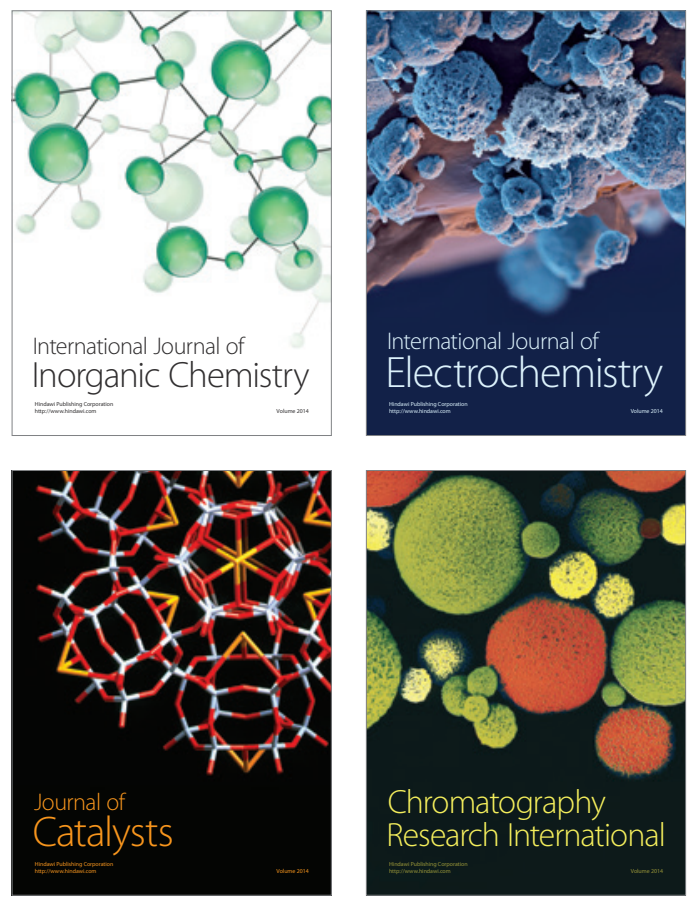
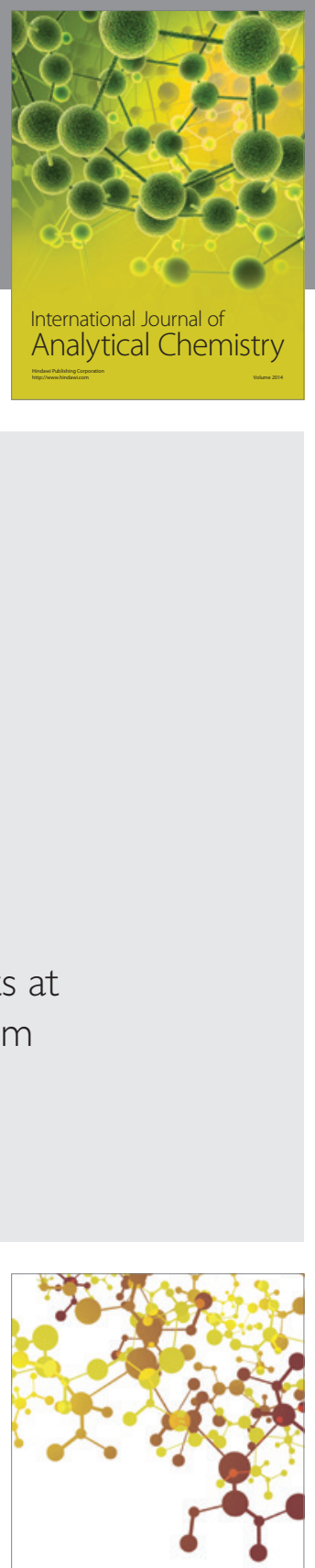

Journal of

Applied Chemistry
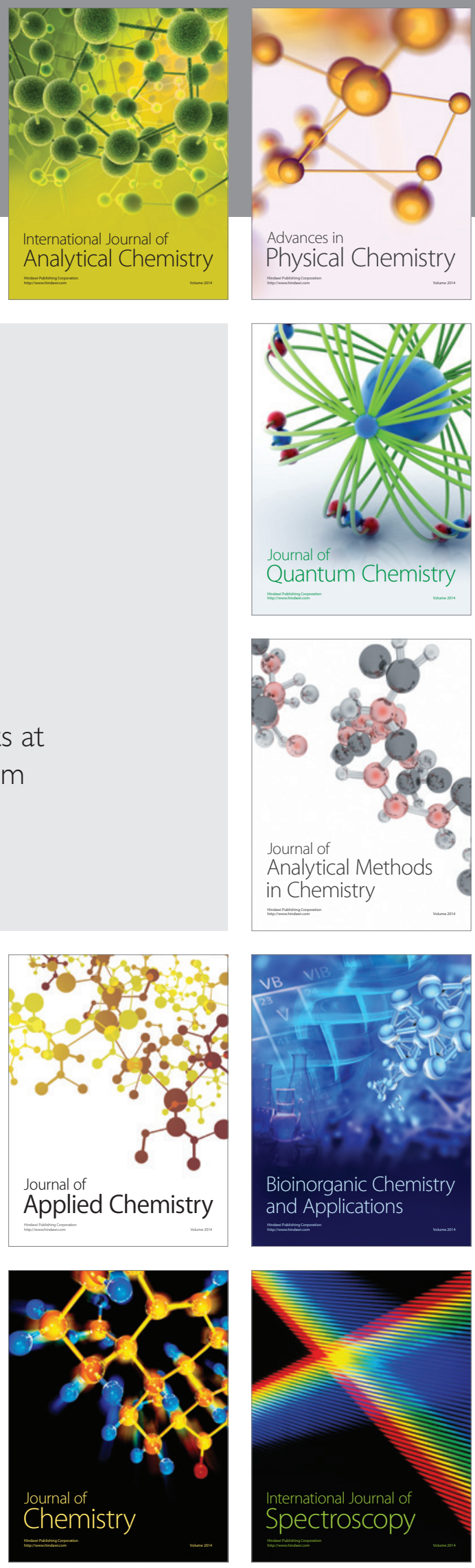